\title{
PITKÄAALTOISEN UV-VALON SEKÄ KASVUNSÄÄTEIDEN VAIKUTUS KRYSANTEEMIN KASVUUN
}

\author{
ErkKi KaUKovirta
}

Helsingin yliopiston puutarhatieteen laitos

Saapunut 7. 2. 1968

Cycocelin (2-kloretyltrimetylammoniumkloridi) ja Phosfonin (tributyl-2,4-diklorbentsylfosfoniumkloridi) pituuskasvua rajoittavan vaikutuksen on todettu olevan erilainen kesällä kuin talvella. Cycocelin kasvua hillitsevä vaikutus on suurempi talvella kuin kesällä, Phosfonin päinvastoin (CAthey 1960 a ja b, CAthey \& Stuart 1961, Kaukovirta 1963). Niistä tekijöistä, joista kyseinen tehon vaihtelu aiheutuu, ei olla täysin selvillä. Tehon vaihtelun selvittämistä vaikeuttaa se, että kasvien pituuskasvun fysiologista taustaa ei vielä riittävästi tunneta (SAcHC 1965).

Pyrittäessä selittämään miten Cycocel ja Phosfon rajoittavat pituuskasvua eri tavalla kesällä ja talvella, kiinnittyy huomio ensiksi valo- ja lämpöolojen erilaisuuteen eri vuodenaikoina. Useat kirjallisuudessa esitetyt tulokset kuitenkin viittaavat siihen, ettei kyseistä tehon vaihtelua voida täysin selittää ainakaan kesän ja talven erilaisista valomääristä ja lämpöoloista aiheutuvaksi. Esimerkiksi WrTTWER (1960) sekä WrTTwER ja Tolbert (1960) totesivat, että valoisuuden lisääntyminen 5000:sta 30000:een luksiin ei vaikuttanut Cycocelin tehoon. Tolbert (1960) havaitsi lisäksi, että Cycocelin pituuskasvua rajoittava vaikutus vehnään pysyi samana lämpötilan muuttuessa $13{ }^{\circ} \mathrm{C}$ :sta $30^{\circ} \mathrm{C}$ :seen. CAthey ja Piringer (1960) totesivat Phosforin pituuskasvua rajoittavan vaikutuksen vähäisemmäksi $27^{\circ} \mathrm{C}$ :ssa kuin $21^{\circ} \mathrm{C}$ :ssa ja $10^{\circ} \mathrm{C}$ :ssa, ts. päinvastaiseksi kuin voisi otaksua sen perusteella, että Phosfon on yleensä kesällä tehokkainta.

Kasvunsääteillä käsiteltyjen kasvien suhtautumista valon laatuun on myös tutkittu (CAthey \& Piringer 1961, Cathey \& Stuart 1961 ja Krug 1961). Lähinnä on verrattu hehkulamppujen ja loisteputkien antamaa valoa valojakson pidentämisessä ja todettu, etteivät kasvunsääteet muuta kasvien suhtautumista kyseisiin valokäsittelyihin. Kasvunsääteiden tehon vaihteluiden selvittämiseksi on valon laadun tarkempi tutkiminen eri vuodenaikoina ilmeisesti tarpeen. On näet ajateltavissa, että valon koostumuksessa tapahtuvat muutokset eri vuodenaikoina voisivat olla syynä kyseisten kasvunsääteiden erilaiseen tehoon kesällä ja talvella. Valon koostumushan vaihtelee auringon korkeuskulman muuttuessa siten, että lyhytaaltoisen säteilyn osuus pienenee korkeuskulman piene- 
tessä. Suomessa suoritetuissa mittauksissa (LuNELUND 1936 ja 1945) on mm. todettu, että auringon korkeuskulman ollessa $50^{\circ}$ on ultravioletin säteilyn osuus 95,4\% keskimääräisestä maksimista, kun taas korkeuskulman ollessa $15^{\circ}$ vain $2.9 \%$. Sinivioletin valon osuus valomäärästä on taas $20.5 \%$ korkeuskulman ollessa $50^{\circ}$ ja $5.9 \%$, kun korkeuskulma on $5^{\circ}$. Sen seikan selvittämiseksi, onko lyhytaaltoisen säteilyn määrällisellä vaihtelulla talven ja kesän aikana mahdollisesti osuutta kasvunsääteiden tehovaihteluun, katsottiin aiheellista tutkia ultravioletin valon vaikutusta Cycocelin ja Phosfonin tehoon krysanteemilla, koska määrälliset vaihtelut UV-valon kohdalla ovat selvimmät. Seuraavassa selostetaan näitä tutkimuksia.

\section{Kokeiden järjestely}

Kokeet suoritettiin v. 1965-1967 Helsingin yliopiston puutarhatieteen laitoksella Viikissä, koe 1 24. 4.-23. 7. 1965, koe 2 24. 2.-18.5. 1966 kasvihuoneessa ja koe 3 kasvatuskaapeissa 25. 3.-13. 7. 1967. Kokeessa 1 ja 3 koelajikkeena oli 'Bonnaffon de Luxe', kokeessa 2 'Goulden Princess Anne'. Kokeessa 1 ja 2 kasvit saivat auringonvaloa, ja UVvalon antamista varten eri koejäsenet oli erotettu toisistaan alumiinipintaisilla väliseinllä. Koe 3 suoritettiin kasvatuskaapeissa, joissa valon lähteinä olivat 'Kuulas valkea'-loisteputket. Valoisuus kaapeissa oli 5000 luksia. Pistokkaat istutettiin lannoitettuun turpeeseen muoviruukkuihin. Kasvunsääteet sekoitettiin multaan ennen istutusta. Valokäsittely aloitettiin heti istutuksen jälkeen ja sitä jatkettiin siihen saakka, kunnes nuput olivat muodostuneet. Käsittelyt olivat seuraavat:

Valokäsittelyt

A Ilman UV-valoa

B UV-valo valojakson aikana, yhteensä 459 t/39 vrk.

C UV-valo pimeäjakson aikana, yhteensä 585 t/39 vrk.

Kokeessa 3 olivat vain käsittelyt A ja C. Valojakson pituus 18 ensimmäisen päivän aikana oli 15 tuntia ja sen jälkeen 9 tuntia vuorokaudessa.

Kasvunsäädekäsittelyt

I käsittelemäton

II Cycocel $15 \mathrm{ml}$ tehoainetta/100 1 multaa

III Phosfon $8.57 \mathrm{~g}$ tehoainetta/100 1 multaa.

Kokeessa 1 Phosfon oli $50 \%$ :n valmisteena ja muissa kokeissa $1.5 \%$ :n jauheena. Cycocelvalmiste oli $50 \%$ :n ja nestemäinen.

Ultraviolettivalon antamiseen käytettiin Philipsin HPW 125 W:n lamppuja, joiden säteilyn maksimi on $3655 \AA$ :ssa, kuten piirroksesta 1 ilmenee. Lamput olivat $70 \mathrm{~cm}$ kasvien latvojen yläpuolella, ja lampun säteilyalue oli $1 \mathrm{~m}^{2}$.

Lämpötila kasvihuoneessa oli helmi-maaliskuussa $18-20^{\circ} \mathrm{C}$ päivällä ja huhtikuun jälkeen $20-22^{\circ} \mathrm{C}$. Yölämpötila ennen lyhytpäiväkäsittelyn alkamista oli $18^{\circ} \mathrm{C}$ ja lyhytpäiväkäsittelyn alettua $16^{\circ} \mathrm{C}$.

Lehden lämpötila mitattiin kahden ensimmäisen viikon aikana kokeesta 1 kolme kertaa vuorokaudessa: tunti lisävalokäsittelyn alkamisen jälkeen, tunti ennen lisävalon katkaisemista ja kerran pimeäjakson aikana. Mittaus suoritettiin vastuslämpömittarilla siten, että kahdesta ohuesta platinakärjestä koostuva tuntoelin asetettiin kevyesti koskettamaan lehden alapintaa. Mittaukset suoritettiin erikseen sisä- ja ulkorivien kasveista. Mittaustulos- 


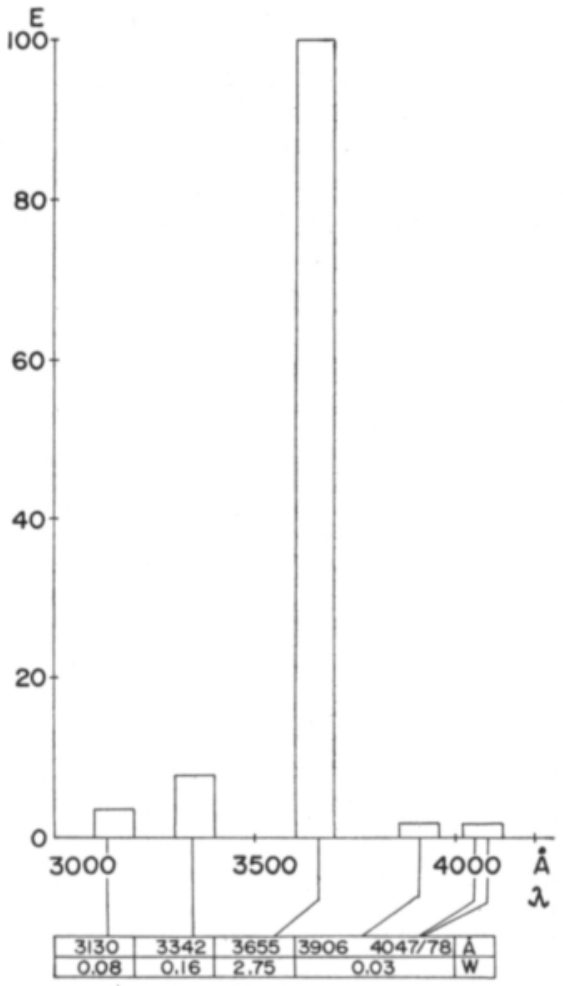

Kuva 1. Philips HPW 125W lampun suhteellinen säteilytiheys.

Fig. 1. Spectral flux distribution of Philips HPW 125W lamp.

ten keskiarvot sekä vaihtelu mittauskertojen välillä esitettiin taulukossa 1. Myöhemmin suoritettiin ainoastaan tarkistusmittauksia, joissa todettiin lämpötilaerojen lisävaloa saaneiden ja ilman lisävaloa kasvaneiden kesken pysyneen samansuuruisina.

Taulukko 1. Keskimääräiset lehden lämpötilat kahden viikon aikana suoritettujen mittausten perusteella.

Table 1. Average leaf temperatures during a two weeks period.

Sisärivien kasvit

Plants in inner rows
Ulkorivien kasvit

Plants in outer rows

Päivällä — Light period

Ilman UV:a

Without $U V$

UV-lisävalo

With $U V$

$20.4 \pm 0.7^{\circ} \mathrm{C}$

$10.2 \pm 0.8^{\circ} \mathrm{C}$

$22.4 \pm 0.8^{\circ} \mathrm{C}$

$21.7 \pm 0.7^{\circ} \mathrm{C}$

Ilman UV:a

Without UV

Yöllä — Dark period

UV-lisävalo

With $U V$

$17.0 \pm 0.5^{\circ} \mathrm{C}$

$17.0 \pm 0.5^{\circ} \mathrm{C}$

$17.8 \pm 0.7^{\circ} \mathrm{C}$

$17.3 \pm 0.5^{\circ} \mathrm{C}$ 


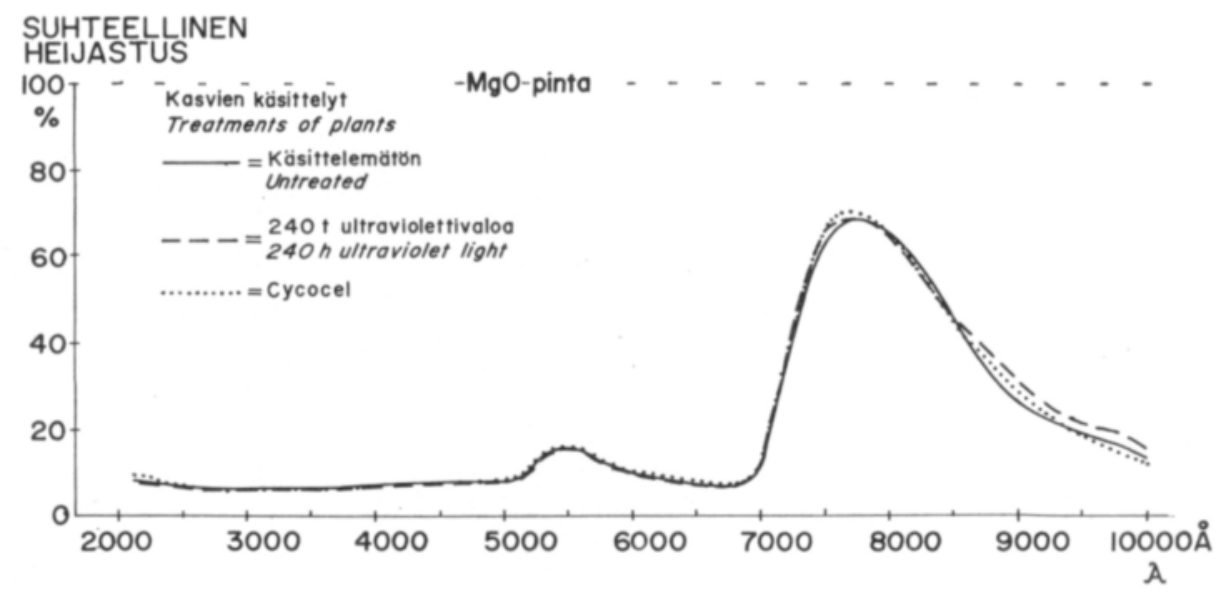

Kuva 2. Krysanteemin lehden heijastumissuhde prosentteina MgO-pintaan verrattuna.

Fig. 2. Relative reflection of chrysanthemum leaves in percentage of reflection from $\mathrm{MgO}$-surface.

Ultraviolettivalon kyky tunkeutua lehtiin määritettiin 'Golden Princess Anne'-lajikkeesta Oy Airam AB:n laboratoriossa mittaamalla suhteellinen heijastus Beckman spektrofotometrillä. Mittaus suoritettiin käsittelemättömistä kasveista, CCC:llä käsitellyistä sekä 10 vuorokautta yhtämittaisesti ultraviolettisäteilyä saaneiden kasvien lehdistä. Tulokset esitetään piirroksessa 2 .

Kokeissa 1 ja 2 ryhmittely perustui osa-osaruutujen ja kokeessa 3 osaruutujen menetelmään. Kokeissa 1 ja 2 sisemmät ja ulommat rivit oli erotettu eri koejäseneksi. Tulosten analysoinnissa seurattiin GouldENin (1952) esittämää laskutapaa.

\section{Tulokset}

P i t u u s k a s v u. Kokeissa 1 ja 2 mitattiin tulokset erikseen ulkoriveissä ja sisäriveissä kasvaneista kasveista. Piirroksessa 3 esitetään tulokset pituuskasvun mittauksista. Ne osoittavat, että UV-valon vaikutus sisä- ja ulkorivien kasveihin oli samanlainen, sillä lisävalo ei merkittävästi muuttanut pituuskasvussa todettuja sisä- ja ulkorivien kasvien välisiä eroja $(\mathrm{F}$-arvot $<2)$. Koska sisä- ja ulkorivien kasvien väliset erot eivät ole merkitseviä, esitetään tulokset seuraavassa keskiarvoina.

Phosfonin ja Cycocelin vaikutus pituuskasvuun. Phosfonin pituuskasvua hillitsevä vaikutus oli selvästi voimakkaampi kuin Cycocelin. Kuten piirroksista 3 ja 4 ilmenee, Phosfonilla käsiteltyjen kasvien pituuskasvu oli kaikissa kokeissa ja koejäsenissä merkitsevästi pienempi kuin käsittelemättömien (PME kokeessa $1=1.1 \mathrm{~cm}$, kokeessa $2=1.6 \mathrm{~cm}$ ja kokeessa $3=1.5 \mathrm{~cm}$ ). Ilman lisävaloa kasvaneissa kasveissa oli Cycocelin pituuskasvua rajoittava vaikutus merkitsevä vain kokeessa 3, UV-valoa saaneissa kasveissa vain kokeessa 3 ja kokeessa 1 pimeä jakson aikana lisävaloa saaneissa kasveissa. Prosentuaalinen pituuskasvun lyheneminen on laskettu taulukkoon 2, josta ilmenee, että Cycocelin ja Phosfonin kasvua hillitsevä vaikutus oli prosentuaalisesti suurempi UVvaloa saaneissa kasveissa kuin ilman sitä kasvaneissa. 
PITUUSKASVU
Stem growth

$\mathrm{CM}$ $\square=$ ULKORIVIT

VISÄRIVIT

Innermost rows

$\mathrm{O}=\underset{\text { KÄSITTELEMÄTÖN }}{\text { Untreated }}$

40f 'BONNAFFON DE LUXE' 24.4.-23.7. $\quad 2$ = PHOSFON
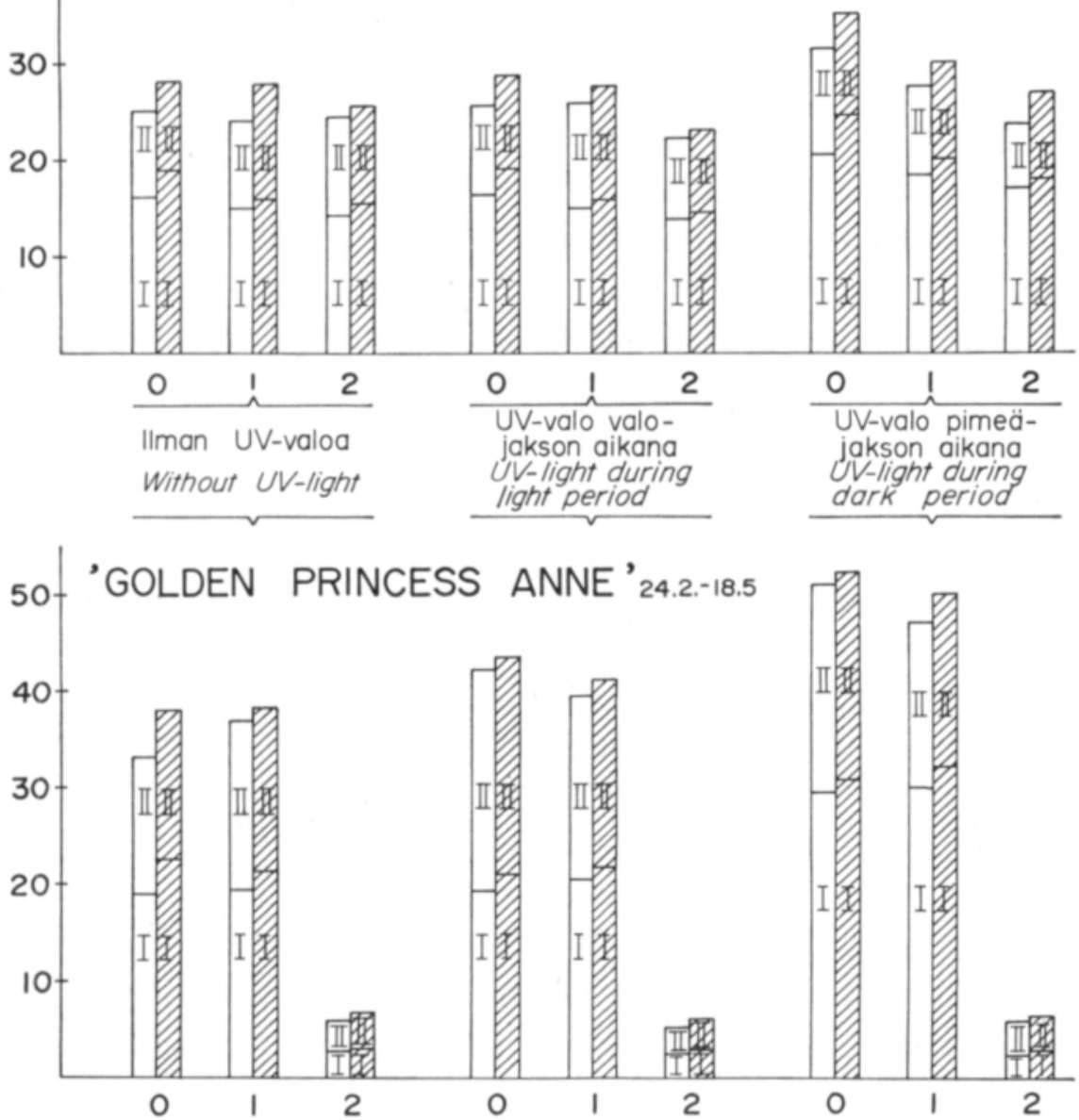

Kuva 3. Pituuskasvu kokeissa 1 ja 2 nuppujen muodostuttua (I), kokeen päättyessä (II).

Fig. 3. Subsequent growth in the experiments 1 and 2 at the time of full flowerbuds $(I)$, at the end of experiments (II).

Taulukosta 2 havaitaan lisäksi, että Cycocelin pituuskasvua rajoittava vaikutus oli 'Bonnaffon de Luxe'-lajikkeessa suurempi kuin 'Golden Princess Anne'-lajikkeessa. Phosfonin kohdalla tilanne oli päinvastainen.

Piirroksissa 3 ja 4 pylväiden alaosa ilmaisee kasvien pituuskasvun siinä vaiheessa, jolloin nuput olivat muodostuneet. Kuten niistä havaitaan, oli Cycocelin ja Phosfonin vaikutus tässä vaiheessa samankaltainen kuin kokeen päättyessä lukuun ottamatta valojakson aikana 
'BONNAFFON DE LUXE'

Kasvatuskaapissa

(In growth cabinet)

$$
\begin{aligned}
& 0=\begin{array}{l}
\text { Käsittelemättömät } \\
\text { Untreated plants }
\end{array} \\
& 1=\text { CCC } \\
& 2=\text { Phosfon }
\end{aligned}
$$

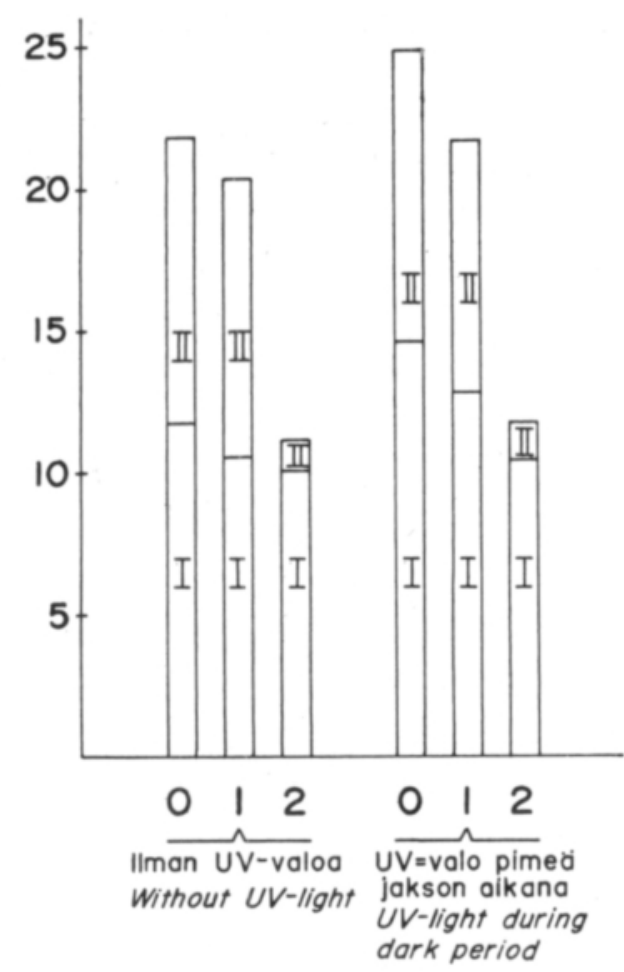

Piirros 4. Kasvien korkeus kokeessa 3 nuppujen muodostuttua (I) ja kokeen päättyessä (II).

Fig. 4. Height of the plants in the experiment 3 at the time of full flowerbuds $(I)$ and at the end of experiment (II).

kokeessa 2 UV-valoa saaneita kasveja, joissa Cycocelilla ei ollut vaikutusta kasvien pituuskasvuun.

UV-valon vaikutus pitu uskasvu n. Piirroksista 3 ja 4 ilmenee edelleen, että UV-valoa saaneiden kasvien pituuskasvu oli suurempi kuin ilman sitä kasvaneiden. Pimeäjakson aikana annettu ultraviolettivalo lisäsi pituuskasvua selvästi enemmän kuin valojakson aikana annettu (PME kokeessa $1=1.8 \mathrm{~cm}$, kokeessa $2=3.3 \mathrm{~cm}$ ja kokeessa $3=1.4 \mathrm{~cm}$ ). Osittain pituuskasvun lisäys aiheutui käsittelemättömissä ja Cycocelillä käsitellyissä kasveissa nivelvälien pitenemistä, kuten taulukosta 3 havaitaan.

Lisäsäteilyn aikaansaama pituuskasvun muutos prosentteina ilman lisävaloa kasvaneista kasveista on laskettu taulukkoon 4. Kuten siitä ilmenee, UV-valon aikaansaama pituuskasvun lisäys oli voimakkainta kokeessa 2, jossa koelajikkeena oli 'Golden Princess Anne'. Kaikissa kokeissa oli kuitenkin yhdenmukaisena piirteenä se, että UV-valon aiheut- 
Taulukko 2. Pituuskasvun lyheneminen (-) Cycocel- ja Phosfon käsittelyjen vaikutuksesta prosentteina käsittelemättömistä kasveista.

Table 2. Growth retardation effect (-) of Cycocel and Phosfon as percentage of untreated plants.

\begin{tabular}{|c|c|c|c|c|}
\hline \multirow[b]{2}{*}{ Koe 1} & \multirow[b]{2}{*}{ Kasvunsääde } & \multicolumn{3}{|c|}{ UV-valo - UV-radiation } \\
\hline & & Ilman & $\begin{array}{l}\text { Valojakson } \\
\text { aikana }\end{array}$ & $\begin{array}{l}\text { Pimeäjakson } \\
\text { aikana }\end{array}$ \\
\hline \multirow[t]{2}{*}{ Experiment } & Growth & & During & During \\
\hline & retardant & None & light period & dark period \\
\hline \multirow[b]{2}{*}{1} & Cycocel & $-1.9 \%$ & $-5.4 \%$ & $-12.0 \%$ \\
\hline & Phosfon & $-15.1 \%$ & $-16.6 \%$ & $-23.4 \%$ \\
\hline \multirow{2}{*}{2} & Cycocel & $+1.9 \%$ & $-1.0 \%$ & $-1.0 \%$ \\
\hline & Phosfon & $-82.7 \%$ & $-86.1 \%$ & $-86.2 \%$ \\
\hline \multirow{2}{*}{3} & Cycocel & $-6.9 \%$ & 一 & $-12.9 \%$ \\
\hline & Phosfon & $-48.9 \%$ & - & $-52.6 \%$ \\
\hline
\end{tabular}

Taulukko 3. Nivelvälien pituus kokeissa 2 ja 3.

Table 3. Length of internodes in Experiments 2 and 3.

\begin{tabular}{lccc}
\hline & UV-valo & UV-radiation & \\
Kasvunsääde & Ilman & Valojakson aikana & Pimeäjakson aikana \\
Growth retardant & None & $\begin{array}{l}\text { During light } \\
\text { period }\end{array}$ & During dark period \\
\hline
\end{tabular}

Koe 2 'Golden Princess Anne'

Experiment 2

$\begin{array}{llllll}\text { Käsittelemätön Check } & 1.9 \pm 0.1 \quad \mathrm{~cm} & 2.1 \pm 0.1 \mathrm{~cm} & 2.5 \pm 0.2 & \mathrm{~cm} \\ \text { Cycocel } & 1.8 \pm 0.1 \quad, " & 2.1 \pm 0.2,, & 2.5 \pm 0.2 & \text {, } \\ \text { Phosfon } & 0.6 \pm 0.0(2), " & 0.7 \pm 0.1, & 0.7 \pm 0.1 & \text {, }\end{array}$

Koe 3 'Bonnaffon de Luxe'

Experiment 3

\begin{tabular}{|c|c|c|c|c|}
\hline Käsittelemätön Check & $1.1 \pm 0.3$ & $\mathrm{~cm}$ & - & $1.3 \pm 0.2$ \\
\hline Cycocel & $1.0 \pm 0.2$ & ,, & - & $1.2 \pm 0.1$ \\
\hline Phosfon & $0.6 \pm 0.0(2)$ &, & - & $0.6 \pm 0.0(2)$ \\
\hline
\end{tabular}

tama pituuskasvun lisäys oli suurin käsittelemättömissä kasveissa ja pienin Phosfonilla käsitellyissä kasveissa. Myös Cycocelilla käsiteltyihin kasveihin ultravioletin lisävalon vaikutus oli selvästi suurempi kuin Phosfonilla käsiteltyihin. Pimeäjakson aikana annettu UVvalo lisäsi pituuskasvua enemmän kuin valojakson aikana annettu.

Käsittelyjen vaikutus kukintaan. Kukinta alkoi kokeessa 1 12.15. 7. välisenä aikana samanaikaisesti kaikissa koejäsenissä. Kokeessa 2 ja 3 Phosfonilla käsiteltyjen kasvien kukinta alkoi 14 päivää myöhemmin kuin muissa koejäsenissä. Kukkien lukumäärä ilmenee taulukosta 5 ja ensimmäisen kukinnon halkaisija taulukosta 6 . Eri käsittelyjen välillä ei kukkien lukumäärissä eikä koossa ollut tilastollisesti merkitseviä eroja. 
Taulukko 4. UV-valon aikaansaama pituuskasvun lisäys $(+)$ la lyheneminen (-) prosentteina ilman UV-valoa kasvaneista kasveista.

Table 4. Change of plant height, promotion $(+)$, retardation $(-)$ caused by UV-light as percentage of plants without $U$ V-light.

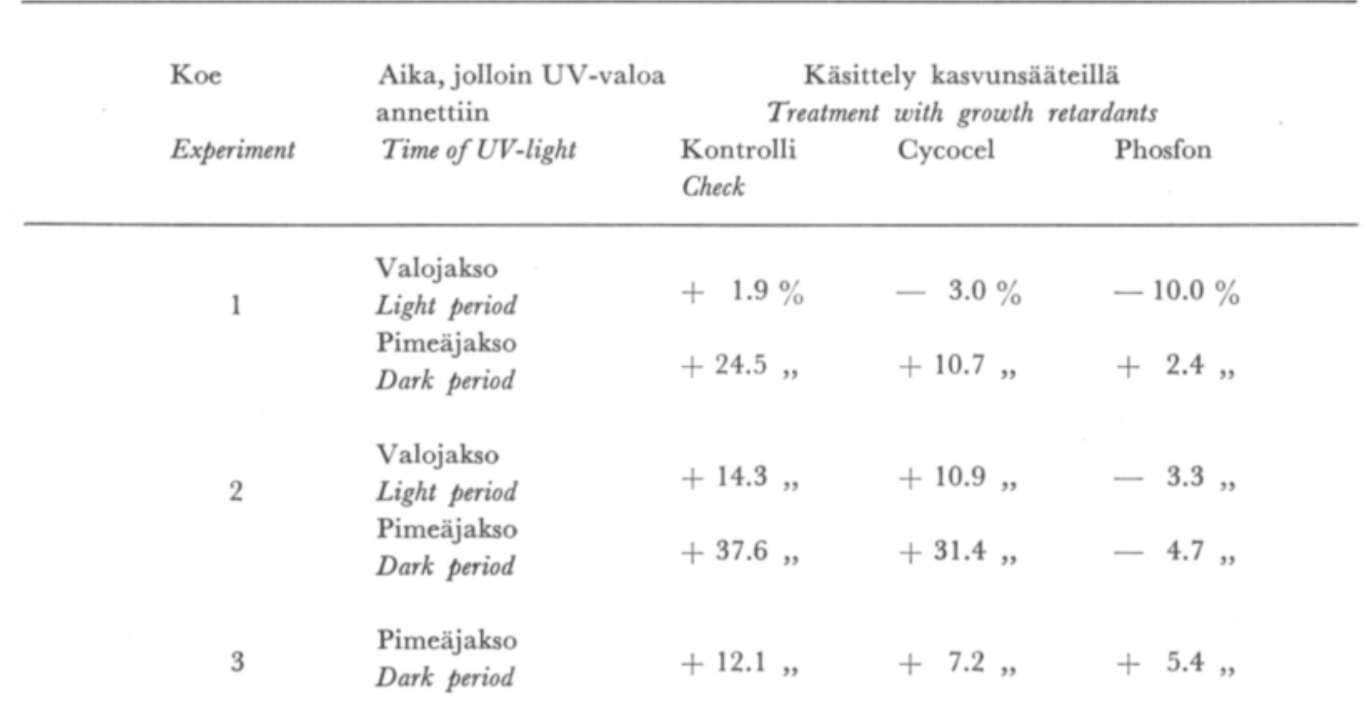

Taulukko 5. Kukkien ja nuppujen yhteismäärä kpl/kasvi.

Table 5. No. of flowers and flower buds per plant.

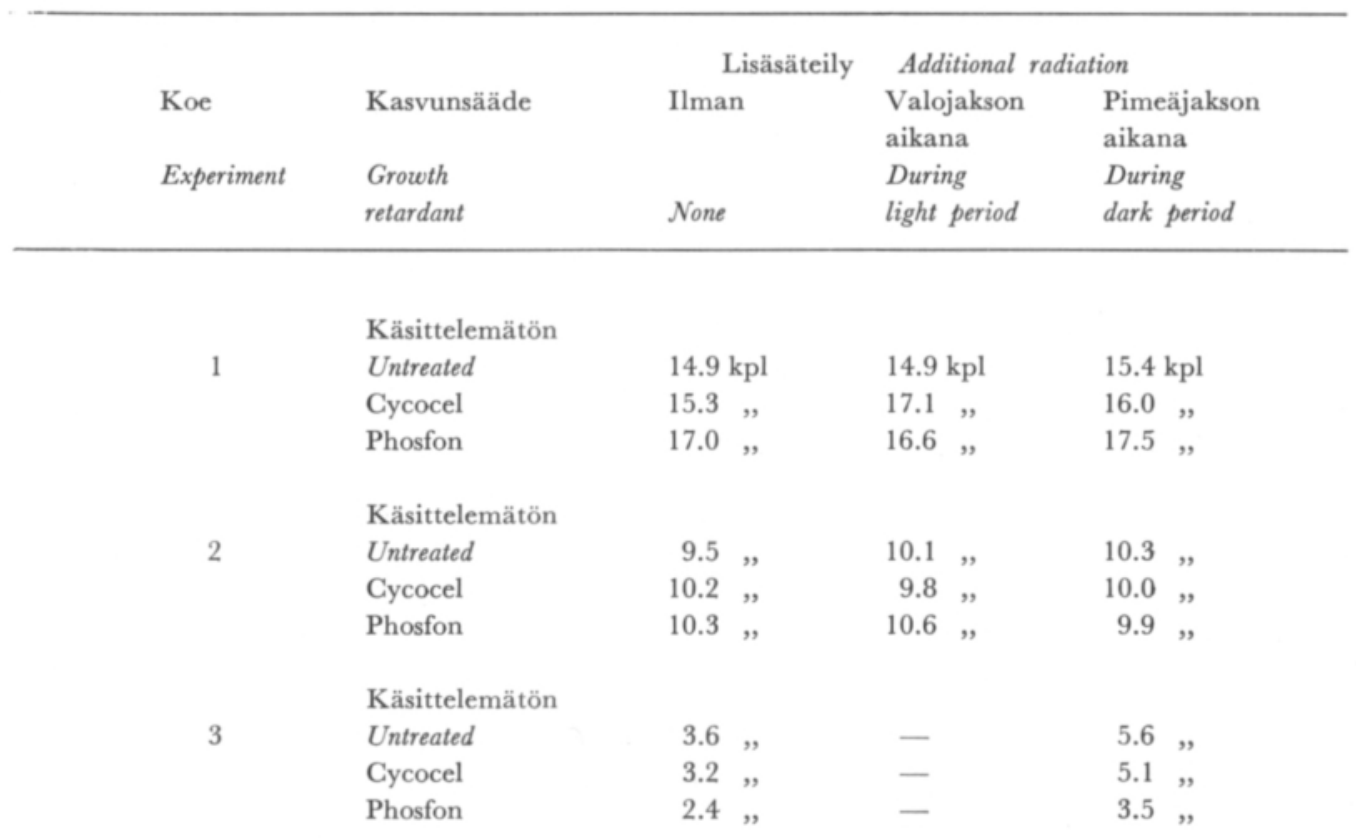


Taulukko 6. Ensimmäisen kukan halkaisija cm.

Table 6. Diameter of 1 st flower in $\mathrm{cm}$.

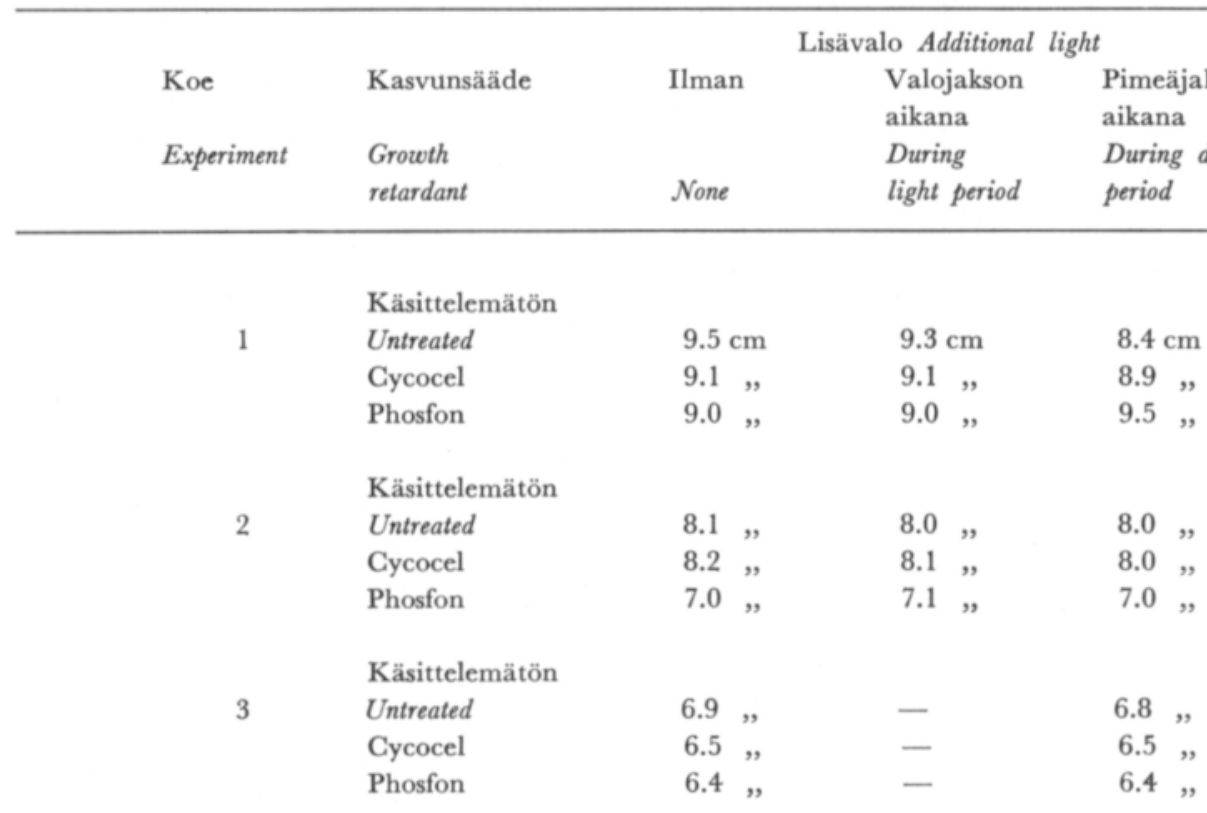

\section{Tulosten tarkastelu}

Ultravioletin valon vaikutus pituuskasvuun. Säteily, jonka aallonpituus on lyhyempi kuin $3000 \AA$, pystyy vain vähäisessä määrin tunkeutumaan tavallisen kasvihuonelasin läpi (TRICKETT \& GouldEN 1958). Tästä syystä valittiin tässä tutkimuksessa ultravioletin valon lähteeksi lamppu, joka pääasiallisesti lähettää $3655 \AA$ :n valoa.

Suoritetuissa mittauksissa todettiin, että vain pieni osa UV-säteilystä heijastui krysanteemin lehdestä, suurin osa tunkeutui lehteen (piirros 2). Samanlainen havainto on tehty myös aikaisemmin Oy Airam Ab:n laboratoriossa (LAMPI 1962). Samoin osoittivat suoritetut mittaukset, että lehden lämpötila nousi ultravioletin säteilyn vaikutuksesta, joskin lämpötilan nousu oli keskimääräisesti pienempi kuin $1^{\circ} \mathrm{C}$ :ta (taulukko 1 ).

Kokeiden tulokset osoittivat, että ultravioletti valo saa aikaan pituuskasvun lisäyksen käsittelemättömissä ja Cycocelilla käsitellyissä kasveissa, mutta vähäisemmässä määrin Phosfonilla käsitellyissä kasveissa. Osittain pituuskasvun lisäys aiheutui nivelvälien pitenemisestä ja oli suurin pimeäjakson aikana UV-valoa saaneissa kasveissa. On siis ilmeistä, että pituuskasvun lisääntyminen ei yksinomaan aiheutunut lisävalon yhteyttämistä edistävästä vaikutuksesta, joskin tämä mahdollisuus on otettava huomioon, sillä eräissä tutkimuksissa on voitu osoittaa yli $3000 \AA$ :n UV-säteilyllä olevan merkitystä yhteyttämisessä (RABINowrtch 1951). Lehtien lämpötilan kohoaminen oli toinen tekijä, joka mahdollisesti saattoi aiheuttaa todetun kasvien »venymisen». Kuitenkin Catheyn ja Piringerin (1961) mukaan Phosfonin teho heikkenee lämpötilan kohotessa. Tätä ei kuitenkaan tapahtunut Phosfonilla käsitellyissä kasveissa, mistä syystä lämpötilan osuus pituuskasvun lisäykseen 
lisäsäteilyä saaneissa kasveissa tulee kyseenalaiseksi. Onkin otaksuttava, että näissä kokeissa UV-lisävalo lähinnä vaikutti joko aktivoivasti tai lisäävästi johonkin pituuskasvua säätelevään aineeseen ja että Phosfon pystyi estämään tästä johtuneen kasvun lisäyksen tehokkaammin kuin Cycocel (taulukko 2). Tämä osaltaan selittänee sen, että Cycocelkäsittelyn antama tulos ei kesällä ole yhtä hyvä kuin talvella. Sen sijaan Phosfon-käsittely pystyy selvästi paremmin hillitsemään UV-valon pituuskasvua lisäävän vaikutuksen.

U V - s ät eilyn va i k u t u s k k i n t a a n. Kukintojen määrä vaihteli huomattavasti eri kokeissa. Kokeessa 3 kukintojen vähäisen määrän voidaan katsoa johtuneen siitä, että kasvatuskaapeissa valomäärä oli alhainen. Tästä huolimatta kaikissa kokeissa todettiin, että ultravioletilla lisävalolla ei ollut fotoperiodista vaikutusta, vaan pimeäjakson aikana lisävaloa saaneissa kasveissa kukinta kehittyi samalla tavalla kuin ilman lisävaloa kasvaneissa tai valojakson aikana ultraviolettivaloa saaneissa kasveissa. Saman ovat todenneet myös Moskov ja MrHajlov (1964). Eräissä tapauksissa ultravioletti valo lisäsi kukintojen määrää, mutta aiheutti samalla kukinnon koon pienenemistä (taulukot 5 ja 6 ).

Ultravioletin valon ei todettu olevan vahingollista kasveille, kuten useissa tutkimuksissa varsinkin lyhytaaltoisen UV-säteilyn on osoitettu olleen (mm. RABINOwITch 1951, VAN Der Veen 1958, Foley 1963, Lomagin 1964).

$\mathrm{K}$ a s vunsääteiden va i k t u s. Phosfon hillitsi krysanteemin pituuskasvua selvästi enemmän kuin Cycocel, kuten aikaisempien tutkimusten perusteella voitiin otaksua (Cathey 1960, Kaukovirta 1964). Phosfon, joka annettiin $1.5 \%$ :n pulverina oli selvästi tehokkaampaa kuin $50 \%$ :n valmiste, jota käytettiin kokeessa 1. Phosfonilla käsiteltyjen kasvien pituus oli lähes sama kaikissa koejäsenissä, mikä osoittaa että se pystyi hillitsemään UV-valon pituuskasvua lisäävän vaikutuksen lähes täysin.

Cycocelin vaikutus oli suurempi loisteputkien valossa kasvatuskaapeissa kuin auringonvalossa kasvihuoneessa suoritetuissa kokeissa. Samoin 'Bonnaffon de Lux'-lajike reagoi voimakkaammin Cycocel käsittelyyn kuin 'Golden Princess Anne'-lajike. Suhteellisesti Cycocelin pituuskasvua rajoittava vaikutus oli suurempi ultraviolettia lisävaloa saaneissa kasveissa kuin ilman lisävaloa kasvaneissa, joskaan se ei riittänut kumoamaan ultravioletin valon pituuskasvua lisäävää vaikutusta. KURAIsHr ja MuIR (1963) ovat todenneet Cycocelin pituuskasvua rajoittavan vaikutuksen johtuvan siitä, että Cycocel alentaa IAA-pitoisuutta. Toisaalta Hall ja Lrverman 1956 sekä De Zeeuw ja Leopold 1957 otaksuvat, että lyhytaaltoinen UV-säteily estää auksiinin vaikutuksen kasveissa. Tämä näyttäisi selittävän Cycocelin suhteellisen tehon lisääntymisen ultraviolettivalon vaikutuksesta. Se, että Cycocel ja Phosfon ehkäisivät eri lailla UV-valosta johtunutta nivelvälien pituuden lisääntymistä, viittaisi siihen, että kyseisten kasvunsääteiden pituuskasvua rajoittava vaikutus on erilainen, kuten KURAISHI ja MuIR (1963) otaksuvat.

\section{Ti ivistel mä}

Suoritetuissa kokeissa tutkittiin ultraviolettisäteilyn (n. $3650 \AA$ ) sekä Cycocelin ja Phosfonin vaikutusta krysanteemin pituuskasvuun. Lisävalona annetun ultraviolettivalon vaikutusta verrattiin auringonvalossa sekä keinovalossa kasvatuskaapeissa. Tutkimuksen tarkoituksena oli selvittää, oliko ultraviolettivalolla mahdollisesti osuutta kasvunsääteiden vuodenaikojenmukaisissa tehon vaihteluissa. 
Kokeet osoittivat, että UV-valo lisäsi käsittelemättömien ja Cycocelilla käsiteltyjen kasvien pituuskasvua, mutta selvästi vähemmän Phosfonilla käsiteltyjen kasvien. Kokeen tulosten sekä kirjallisuudessa esitettyjen tietojen perusteella voitiin otaksua, ettei kyseinen pituuskasvun lisääntyminen kokonaisuudessaan aiheutunut UV-lisävalon yhteyttämistä lisäävästä eikä lisäsäteilyn lehden lämpötilaa kohottavasta vaikutuksesta, vaan siihen oli todennäköisimmin syynä myös UV-valon vaikutus pituuskasvua sääteleviin kasvuaineisiin. Kokeen tulosten perusteella on otaksuttavissa että UV-valon suurempi määrä kesällä on ainakin osittain syynä siihen, että Cycocelin teho näennäisesti tällöin on vähäisempi kuin talvella.

Ultravioletilla valolla ei ollut fotoperodista vaikutusta, eikä sen todettu vahingoittavan kasveja.

Phosfon hillitsi krysanteemin pituuskasvua enemmän kuin Cycocel. Cycocelin vaikutus 'Bonnaffon de Lux'-lajikkeeseen oli suurempi kuin 'Golden Princess Anne'-lajikkeeseen pituuskasvun lyhenemisen mukaan arvosteltaessa. Phosfonin kohdalla tilanne oli päinvastainen.

Kokeen tulokset tukevat niin ikään sitä käsitystä, että Cycocelin ja Phosfonin pituuskasvun hillintä perustuisi erilaiseen vaikutukseen kasveissa.

\section{KIRJALLISUUTTA}

CAtheY, H. M. 1960a. Phosfon and CCC for controlling height of chrysanthemums. Flor. Exch. 135: $12-13$.

"1960b. Growth retardants Phosfon and CCC for controlling mum height. Flor. Rev. 126: 17-18, $43-44,52$.

" \& Piringer, A. A. 1961. Relation of Phosfon to photoperiod, kind of supplemental light, and night temperature on growth and flowering of garden annuals. Proc. Amer. Soc. Hort. Sci. 77: $608-619$.

" \& Stuart, N. W. 1961. Comparative plant growthretarding activity of Amo 1618, Phosfon and CCC. Bot. Gaz. 123: 51-57.

Foley, R. F. 1963. A physiological disturbance caused by solar ultraviolet radiation that is affecting some vegetable crops in Idaho. Proc. Amer. Soc. Hort. Sci. 83: 721-727.

Goulden, C. H. 1952. Methods of statislical analysis. 467 p. New. York.

Hall, W. C. \& Liverman, J. L. 1956. Effect of radiation and growth regulators on leaf abscission in seedling cotton and bean. Plant. Physiol. 31: 471-476.

KAUкovirt^, E. 1963. Kasvua hillitsevien aineiden käytöstä krysanteemin ja joulutähden viljelyssä. Maatal. tiet. Aikak. 35: 109-126.

" 1964. Om inverkan av tillväxthämmande, medel på chrysanthemum och julstjärna. Nord. Jordbr. Forsk. 1964. Suppl. 8: 309-311.

Kuraishi, S. \& Muir, R. M. 1963. Mode of action of growth retarding chemicals. Plant Physiol. 38: 19-24.

LAMP1, E. 1962. Kasvien valottaminen valoteknillisenä ongelmana. Voima ja Valo 1962, 2. Eripainos 3s.

LomagrN, A. G. 1964. Vlijanie teplovoj zakalki na razvitie povtreždenija vyzvannogo ultrafioletovymi lučami v ractitelnyh kletkah. Doklady Akad. Nauk. SSSR. 157: 1477-1479.

Moskov, B. S. \& Mrhazlov, A. P. 1064. Vlijanie ultrafioletovoi radiacii na temnovyja fazu aktinoritmučeskoj reakcii ractenij. Ibid. 158: 990-992.

Rabinowitch, E. J. 1951. Photosynthesis and related processes. II, 1:603-1208.

SACHs, R. M. 1965. Stem elongation. Ann. Rev. Plant. Physiol. 16: 73-96.

ToLBert, N. E. 1960. (2-chloroethyl-) trimethylammonium chloride and related compounds as plant growth substances. II. Effect on growth of wheat. Plant Physiol. 35: 380-385. 
Trickett, E. S. \& Goulden, J. D. S. 1958. The radiation transmission and heat conversing properties of glass and some plastic films. J. Agric. Engin. Res. 3: 281-287.

Van Der VeEN, R. 1958. Plant growth in colored light. Sci. Hort. 13: 33-37.

WrtTwer, S. H. 1960. Eine neue Gruppe von Wuchsstoffen und einige ihrer Wirkungen auf die Pflanze im Vergleich zu denen von Auxin und Gibberellin. Gartenbauwissenschaft. 25: 236-248.

WrtTwer, S. H. \& Tolbert, N. E. 1960. (2-chloroethyl-) trimethylammonium chloride and related compounds as plant growth substances. III. Effect on growth and flowering of the tomato. Amer. J. Bot. 47: 560-565.

De Zeeuw, D. \& Leopold, A. C. 1957. The preventation of auxin responses by ultraviolet light. Ibid. 44: $225-228$.

\title{
SUMMARY
}

\section{THE EFFECT OF NEAR UV-LIGHT, CYCOCEL AND PHOSFON ON THE GROWTH OF CHRYSANTHEMUM}

\section{ERKKI KaUkovirta}

\author{
Institute of Horticulture, University of Helsinki
}

Natural daylight conditions in Finland vary considerably during summer and winter months, not only as regards the amount but also the quality of light. The proportion of radiation with short wave bands to total radiation is lower in winter than in summer owing to the leight of the sun. For example, when the elevation of the sun is $50^{\circ}$ the amount of near UV-light is $95.4 \%$ of its average maximum but when the elevation of the sun is $15^{\circ}$ the corresponding figure is $2.9 \%$ (LuNELUND 1936 and 1945 ).

Little attention has been paid to this variation in light quality in horticultural research in this country. A study of how this type of variation in the quality of light might affect the growth of horticultural crops therefore seemed justified. This paper is a report of experiments in which the effect of near UV-light on the growth of chrysanthemum has been studied.

In the experiments (1965-1967) chrysanthemum cuttings were treated with Cycocel and Phosfon. Treated and untreated cuttings were subjected to near UV-supplementary light (see Fig. 1) both during light and dark periods. UV-supplementary light was given during 39 days starting from planting. Two of the experiments were carried out in natural light conditions and one under artificial light in growth cabinets equipped with 22 Philips TLA $80 \mathrm{~W} / 55$ fluorescent tubes. The results are given in Tables $2-6$ and in Figures 3 and 4.

In each experiment the near UV was found to increase the stem elongation of chrysanthemum. This increase was due partly to the increased length of the internodes. The effect of UV-light was greatest on plants not treated with growth retardants and more pronounced in plants treated with Cycocel than in plants treated with Phosfon. The UV-light given during dark periods resulted in higher plants than UV given during light periods.

The UV-supplementary light did not have any photoperiodic effect and no harmful effect other than the stem elongation was observed. 